\title{
Construction of Information Quality Index System for Police College
}

\author{
Liang $\mathrm{HU}^{1,2}$ \\ ${ }^{1}$ JiangXi Police College, NanChang City, Jiangxi Province, P.R.China \\ ${ }^{2}$ Collaborative Innovation Center for Economics crime investigation and prevention technology, Jiangxi Province, P.R.China \\ huliang_thu@163.com
}

\begin{abstract}
With the development of the information age, information quality has become an important indicator of College Students' evaluation system. This paper introduces the status of information quality of college students in public security colleges and universities, emphasizes the importance of establishing a national unified index system, and puts forward a model of information quality index for public security students.
\end{abstract}

Keywords-Information quality; index model; public security; college student

\section{INTRODUCTION}

With the development of information technology, electronic policing is more and more widely used in the public security industry, which puts forward higher requirements for the information skills of police officers in China. As the reserve force of our modem police officers, the police academy police will not only directly participate in the construction of public security information, but also serve the public on behalf of public power. Their basic qualities represent the image of the public security organs in the eyes of the public [1][2]. Therefore, how to strengthen the training of the information quality of the police in public security institutions and to strengthen their comprehensive quality and learning ability have become a realistic problem to be discussed and solved urgently. Information quality is the comprehensive ability of individuals to acquire, evaluate and effectively utilize information from various sources [3]. Information quality education is very important for the school police in public security colleges and universities, which can make the students collecting information through information skills in the future posts and improve their work efficiency.

\section{VALUE AND SIGNIFICANCE OF INFORMATION QUALITY TRAINING}

Police information quality refers to the police's selfcultivation and ability to deal with information activities gradually formed in the practice of cracking down on crime and strengthening the management of public order, according to the development requirements of the information environment inside and outside the organization and consciously accepting relevant education and training.

This author's work is supported by JiangXi Science and Technology Research Project of Education Department(GJJ151193), JiangXi University Party Building Project(16DJQN065), JiangXi Police College Scientific Research Project(2016JGZB008) and JangXi Science Education Planning Project(17YB244).
Information quality of public security college students is of great importance to the future policing work [4][5]. It is an important subject of public security education and teaching to analyze the present situation of information quality of university students in public security colleges, find out the existing problems, and try to explore the strategies of improving information quality of university students in public security colleges.

Information quality of public security college students has become one of the important objectives of public security education, and is an important content of quality education for public security college students. The information quality evaluation of public security students needs to formulate specific training standards and combine the evaluation of information quality with their academic achievements so as to measure the information quality of public security students more effectively.

\section{STATUS OF INFORMATION QUALITY OF PUBLIC SECURITY COLLEGE STUDENTS}

In the Internet age, the students of Public Security Colleges and universities have a strong sense of information, can recognize the importance of information, and have a strong demand for information, but this demand for information is broad, lack of professionalism. For example, the lack of professional role awareness, lack of awareness of information or information closely related to public security work, and the limited access to public security information due to the confidentiality of public security information, is also an important factor restricting public security students to obtain professional information.

1) Information retrieval: Public security college students have mastered the skills of network information retrieval, but the efficiency and effect of obtaining information need to be improved.

2) Information course: Although public security students have offered courses related to information theory, the curriculum system needs to be further improved.

3) Information analysis: Public security college students have a strong ability of information discrimination, can make effective screening in a large number of information sources, delete error information, but the ability of data analysis needs to be strengthened. 


\section{STRUCTURE OF INFORMATION QUALITY EDUCATION}

The concept of information quality was first proposed by Paul Zurkowski, president of the American Association for the Information Industry, and is defined as "the use of information technology and skills when answering questions using a large number of information tools and major sources of information". Police information quality refers to the police's self-cultivation and ability to deal with information activities gradually formed in the practice of cracking down on crime and strengthening the management of public order, according to the development requirements of the information environment inside and outside the organization and consciously accepting relevant education and training.

Information quality education must be designed in content and form in accordance with the knowledge level and information needs of Public Security College students, attach importance to learner-centered, according to the cognitive characteristics of college students to organize knowledge content, and provide interactive learning methods. To provide a suitable learning environment for learners, so that learners can actively construct their own information knowledge and ability according to their own interests and needs. According to the theory of knowledge construction, the information quality education in Colleges and universities should establish an information quality education system with multi-level teaching objectives, multi-level teaching contents and various forms of education to improve the information quality of College students.

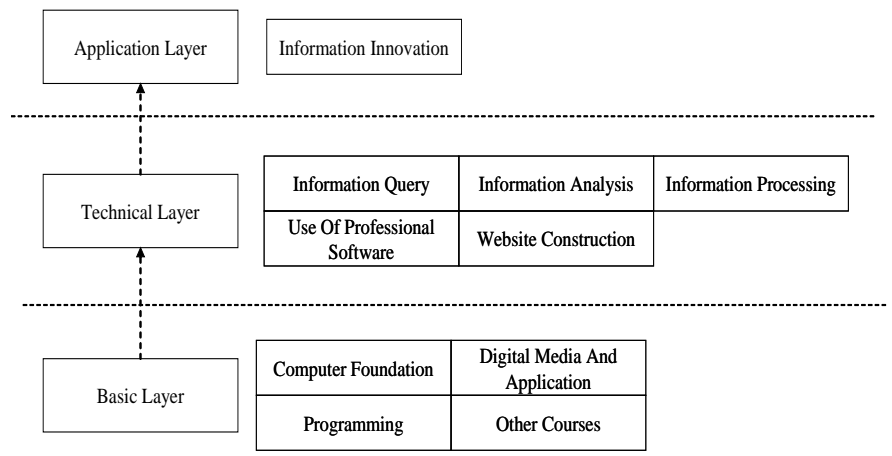

FIG.1. Level structure of information quality

Basic level is mainly the cultivation of general information quality, including: computer foundation, digital media and application, programming and other courses.

Technical level is mainly the cultivation of professional information quality, mainly including: professional information query, analysis and processing, the use of professional software, professional website construction.

Application level is mainly the cultivation of practice and innovative information quality, so that college students can make full use of information technology to carry out research and practice, and preliminarily train their ability to apply information technology to innovation.

\section{INFORMATION QUALITY INDEX MODEL}

Referring to the experience of information quality education at home and abroad, this paper puts forward the standard system of information quality education in public security colleges, in order to improve the information quality ability and teaching effect of students in public security colleges, and promote the development process of information quality education in public security colleges in China. The information quality model of public security college students consists of information consciousness, information knowledge, information skills and information application.

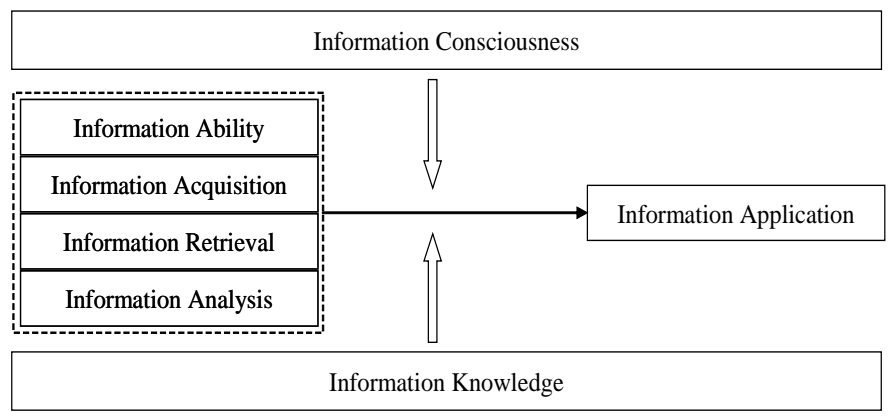

FIG.2. Information quality model

1) Police Information Consciousness: it refers to the psychological qualities of the police, such as feeling, perception, emotion, will, etc.

2) Police Information Knowledge: it refers to the police's understanding of the basic knowledge of information, and their mastery of information sources, information retrieval tools and retrieval methods. Information knowledge is an important part of information quality. The degree of mastery of information knowledge is related to the strength of police information awareness and information skills.

3) Police Information Ability: it refers to the ability of obtaining, analyzing, processing and applying information that the police should possess in police work.

4) Police Information Application: it refers to the process of integrating information and making use of information to achieve the purpose of information.

Information quality model has two levels of indicators, the first level indicators for information awareness, information knowledge, information skills, information applications, the second level indicators for information sensitivity, information security, information ethics, general knowledge, basic knowledge, professional knowledge, information acquisition, information retrieval, information retrieval information analysis, information reorganization, information innovation and information evaluation. 
TABLE I. INFORMATION QUALITY INDEX

\begin{tabular}{|c|c|c|}
\hline & First Level Index & Second Level Index \\
\hline \multirow{12}{*}{$\begin{array}{l}\text { Information } \\
\text { Quality Index }\end{array}$} & \multirow{3}{*}{ Information Consciousness } & Information Sensitivity \\
\hline & & Information Security \\
\hline & & Information Ethics \\
\hline & \multirow{3}{*}{ Information Knowledge } & General Knowledge \\
\hline & & Basic Knowledge \\
\hline & & Professional Knowledge \\
\hline & \multirow{3}{*}{ Information Ability } & Information Acquisition \\
\hline & & Information Retrieval \\
\hline & & Information Analysis \\
\hline & \multirow{3}{*}{ Information Application } & Information Reorganization \\
\hline & & Information Innovation \\
\hline & & Information Evaluation \\
\hline
\end{tabular}

\section{DISCUSSION AND FUTURE WORK}

The actual need of public security work is to make good use of information to meet the police work in the information age. The essence of information quality is the ability to understand and use various kinds of information. It is an important quality and high-level cognitive skills that policemen must have. As a public security academy, the school police should recognize the function and function of information, realize the effectiveness of information to its own learning and after-school scientific research activities, form a positive experience of information, and then produce the information demand and information behavior tendency to adapt to the learning.

\section{ACKNOWLEDGMENT}

This author's work is supported by JiangXi Science and Technology Research Project of Education Department(GJJ151193), JiangXi University Party Building Project(16DJQN065), JiangXi Police College Scientific Research Project(2016JGZB008) and JangXi Science Education Planning Project(17YB244).

This author's work also is supported by the Opening Project of Collaborative Innovation Center for Economics crime investigation and prevention technology, Jiangxi Province.

\section{REFERENCES}

[1] Song Yong. A Brief Analysis of Police Academic Information Quality in the Information Age[J]. Heilongjiang Science and Technology Information, 2015 (11). (in Chinese)

[2] Ding Yu. On information quality standards of students in public security colleges[J]. Information exploration, 2012 (8). (in Chinese)

[3] Xie Shaojun. Information Quality Education in Public Security Colleges: Problems and Countermeasures[J]. Journal of South China Normal University, 2009 (3). (in Chinese)

[4] Yang Xiaoguang, Chen Wenyong. Evaluation of Information Quality Education and Core Competence of Information Quality[J]. Information Journal, 2001 (5): 87-88. (in Chinese)

[5] Zhao Li, investigation and Study on the information quality of Police Academies in public security colleges in the new era[D]. Dalian: Liaoning Normal University, 2006. (in Chinese) 